\title{
Peningkatan Keterampilan Berpikir Kritis dan Hasil Belajar Siswa SD dengan Menerapkan Strategi Everyone is A Teacher Here pada Model Pembelajaran Kooperatif
}

\section{Mochamad Yusuf*}

STKIP Bina Insan Mandiri

\section{A R T I C L E I N F O \\ Article history: \\ Received 20 Desember 2017 \\ Received in revised form 6 januari 2018 \\ Accepted 19 Januari 2018 \\ Available online 20 \\ Februari 2018}

Kata Kunci:

Semua orang adalah guru

Strategi di sini,

Pembelajaran Kooperatif,

Kemampuan berpikir kritis,

Hasil Belajar.

Keywords:

Everyone is a Teacher Here's strategy, Cooperative Learning,

Critical thinking skills,

Results Study.

\begin{abstract}
A B S T R A K
Tujuan penelitian ini adalah untuk mendeskripsikan aktivitas guru, aktivitas siswa, peningkatan keterampilan berpikir kritis siswa, peningkatan kemampuan kognitif, dan mengetahui respon siswa terhadap pelaksanaan pembelajaran dengan menerapkan strategi Everyone is a Teacher Here pada model pembelajaran kooperatif. Peneliti menggunakan metode Penelitian Tindakan Kelas (PTK). Subyek dan lokasi penelitian ini adalah siswa kelas IV SD Hidayatul Mubtadiin yang berjumlah 26 siswa. Instrumen yang digunakan pada penelitian ini terdiri lembar observasi aktivitas guru, lembar observasi aktivitas siswa, tes keterampilan berpikir kritis, tes hasil belajar kognitif, lembar observasi hasil belajar afektif siswa, lembar observasi hasil belajar psikomotor siswa, dan angket respon siswa. Hasil penelitian menunjukkan bahwa aktivitas guru, aktivitas siswa, hasil belajar kognitif, afektif maupun psikomotor siswa mengalami peningkatan yang signifikan selama dua siklus dengan masing-masing persentase ketuntasan mencapai indikator yang ditentukan. Pembelajaran dengan menerapkan strategi Everyone is a Teacher Here pada model pembelajaran Kooperatif mendapat respon positif dari siswa sehingga layak diterapkan oleh guru.
\end{abstract}

\section{A B S T R A C T}

The purpose of this research was assess the activity of teachers, students, enhancement of critical thinking skils student, results cognitive study, and to know student respon for learning that applied "Everyone is a Teacher Here"strategy for cooperative models. Research used Classroom Action Research (CAR)methods. The subjects and the location of research was fourth grade students of Hidayatul Mubtadiin Primary School, amounting to 26 students. The instrument used in this research consisted of sheet of observation teachers activities, sheets of observation of students avtivities, critical thinking skills test, cognitive results studies test, sheets of observation of afective results studies test, sheets of observation of psicomotoric results studies test, and sheets of respons students. The result showed that the activity of teacher, the activity of students, critical thinking skills, and the student's results study was increase significantly during two cycles with their respective percentage of completeness. Learning of applying "Everyone is a Teacher Here" strategy for Cooperative models got positive respons from students so worthy to be applied by the teacher.

\footnotetext{
${ }^{1}$ Corresponding author.

E-mail addresses: - Mochamad Yusuf9@gmail.com (Mochamad Yusuf)
} 


\section{Pendahuluan}

Pendidikan pada abad ke 21 sekarang tidak hanya mengacu pada penguasaan membaca, menulis, dan berhitung saja (Trilling \& Fadel, 2009). Namun ditekankan pada penguasaan keterampilanketerampilan tingkat tinggi. Wagner(2008)menyatakan bahwa yang diperlukan setiap orang untuk tetap hidup (survival skills) di abad ke 21 meliputi, berpikir kritis dan pemecahan masalah, kolaborasi melalui jaringan dan memimpin berlandaskan pengaruh, ketangkasan dan kemampuan beradaptasi, komunikasi yang efektif, mengakses dan menganalisis informasi, rasa ingin tahu dan imajinasi.

Pengertian berpikir kritis telah dikemukakan oleh beberapa ahli. Menurut Lau, (2011:1) berpikir kritis merupakan berpikir secara jelas, rasional, tepat, sistematis, dan ilmiah. Menurut Dean \& Kuhn, (2003:3) berpikir kritis memperlukan kesadaran pemikiran diri sendiri serta refleksi tentang diri sendiri dan orang lain sebagai objek kognitif. Menurut Yanfa'ani, Maridi, \& Dwiastuti, (2015), berpikir kritis adalah berpikir runtut yang dikendalikan oleh standar-standar yang jelas yaitu kejelasan, ketelitian, ketepatan, keterkaitan, konsistensi, logis, dan kejujuran.

Berpikir memiliki banyak manfaat dalam kehidupan sehari-hari. Menurut Bassham, dkk.(2011:3), berpikir kritis tidak membuat materi-materi pelajaran sekolah yang sulit menjadi mudah dipahami, namun berpikir kritis mengajarkan berbagai keterampilan berpikir yang bila dipraktikkan secara signifikan maka dapat meningkatkan kemampuan dalam memahami argumen dan isu yang dibahas dalam buku pelajaran. Selain itu, berpikir kritis dapat membantu kita agar terhindar dari membuat keputusankeputusan yang tidak tepat. Menurut Facione (1990), berpikir kritis merupakan faktor yang sangat penting dalam menghasilkan interpretasi, analisis, evaluasi, dan kesimpulan, serta penjelasan berdasarkan bukti, konsep, metodologi, kriteria, atau pertimbangan konstektual yang dijadikan landasan pertimbangan. Dengan demikian, berpikir kritis merupakan sumber daya yang besar dalam kehidupan pribadi dan sosial seseorang.

Dalam kegiatan pembelajaran di kelas, peneliti menjumpai beberapa permasalahan yang berkaitan dengan pembelajaran IPA di kelas IV SD Hidayatul Mubtadiin Kota Pasuruan yaitu guru masih mendominasi pembelajaran dengan metode ceramah atau disebut juga dengan pembelajaran konvensional. Metode ini dipilih guru karena ingin mengejar tuntutan kurikulum, dimana dengan waktu yang relatif singkat semua materi harus sudah selesai diajarkan. Pola mengajar kelihatan baku, yakni menjelaskan sambil menulis di papan tulis serta diselingi tanya jawab, sementara itu siswa memperhatikan penjelasan guru sambil mencatat dibuku tulis. Proses pembelajaran masih didominasi kesibukan guru menyampaikan materi, siswa dituntut mendengarkan dengan tertib tanpa mengetahui maksud dan tujuannya. Guru kurang memperhatikan dan memanfaatkan potensi-potensi siswa secara keseluruhan. Dari permasalahan tersebut dapat disimpulkan bahwa pembelajaran yang terjadi masih berpusat pada guru.

Hal tersebut di atas mengakibatkan siswa cenderung pasif, enggan bertanya dan tidak banyak mengembangkan keterampilan berpikirnya. Selain itu hanya beberapa siswa saja yang aktif jika diadakan pembelajaran dengan diskusi. Siswa tidak terlibat langsung dalam pembentukan pemahaman dalam pembelajaran tersebut. Siswa hanya dapat menerima informasi yang telah disampaikan oleh guru, tanpa mengetahui maksud dan tujuan dari informasi tersebut. Sehingga keterampilan berpikir kritis siswa pada mata pelajaran IPA tidak maksimal.

Rendahnya keterampilan berpikir krisis dapat dikarenakan guru tidak merencanakan pembelajaran yang mengembangkan keterampilan berpikir kreatif secara maksimal (Fauziah, 2011). Hal tersebut didukung wawancara dengan beberapa guru di SD Hidayatul Mubtadiin. Berdasarkan hasil wawancara, siswa masih belum banyak dilatih keterampilan berpikir kritis karena keterbatasan ide startegi pembelajaran yang digunakan untuk meningkatkan keterampilan berpikir kritis.Sehingga, menyebabkan rendahnya keterampilan berpikir kritis siswa di SD Hidayatul Mubtadiin. Selain itu berdasarkan data tes awal di lapangan, ditemukan fakta bahwa masih banyak siswa yang mendapatkan nilai keterampilan berpikir kritis yang rendah pada pembelajaran IPA. Hasil tes awal yang dilakukan kepada siswa SD Hidayatul Mubtadiin menunjukkan bahwa hanya 11 siswa (44\%) dari 26 siswa mendapatkan kriteria sedang dalam keterampilan berpikir kritis dan sisanya berkriteria kurang. Hal ini dapat diartikan bahwa pembelajaran di kelas tersebut belum berhasil dalam meningkatkan keterampilan berpikir kritis siswa.

Melihat kenyataan tersebut, kelemahan-kelemahan dalam pembelajaran IPA seperti yang diuraikan diatas, haruslah segera dipecahkan dengan menggunakan suatu pendekatan pembelajaran yang tepat. Pemilihan dan penerapan pendekatan pembelajaran yang tepat dapat membantu siswa untuk meningkatkan kemampuan sesuai tujuan pembelajaran yang ingin dicapai Yusuf, (2018). Pemilihan berbagai strategi dan model pembelajaran yang digunakan dalam proses pembelajaran turut menentukan keefektifan pembelajaran. Karena salah satu faktor penentu keberhasilan suatu pembelajaran menurut 
Ainurrahman, (2011:143) adalah kemampuan dan keterampilan guru dalam pemilihan strategi dan model pembelajaran untuk menumbuhkan rasa senang siswa terhadap pelajaran, menumbuhkan dan meningkatkan motivasi dalam mengerjakan tugas, dan memberikan kemudahan bagi siswa untuk memahami pelajaran sehingga memungkinkan siswa mencapai hasil belajar yang optimal.

Oleh karena itu, perlu dicari alternatif strategi dan model pembelajaran yang dapat memacu semangat setiap siswa secara aktif ikut terlibat dalam pengalaman belajarnya, memberikan kesempatan pada siswa untuk mengadakan diskusi pada proses pembelajaran, mampu memberikan kesempatan pada siswa untuk belajar mencari, menemukan, menyimpulkan, dan mengkomunikasikan sendiri berbagai pengetahuan, nilai-nilai dan pengalaman yang dibutuhkan, dan yang mampu membuat siswanya aktif secara keseluruhan dalam mengembangkan keterampilan berpikirnya.

Sebagai jalan keluar terbaik atau alternatif yang inovatif yang dapat meningkatkan hasil belajar siswa dalam proses belajar mengajar IPA, guru harus mengubah cara mengajarnya yang dapat membuat siswa aktif secara keseluruhan di kelas pada saat proses pembelajaran berlangsung. Salah satu caranya yaitu dengan menerapkan strategi pembelajaran aktif tipe Everyone is a Teacher Here pada pembelajaran kooperatif pada materi yang sedang dipelajari.

Pemilihan penerapan strategi Everyone is a Teacher Here pada model pembelajaran kooperatif ini, karena dalam strategi dan model pembelajaran ini siswa dituntut aktif dalam kelompok untuk mengerjakan tugas kelompok, menjawab pertanyaan maupun menyampaikan di depan kelas, dan menjelaskan apa yang sudah dipelajari kepada teman-teman mereka di depan kelas. Bukan hanya itu, dengan menggunakan strategi ini akan terjadi diskusi kelas membahas permasalahan yang muncul selama kerja kelompok, mendiskusikan solusi dari permasalahan tersebut dengan banyak pendapat dari temanteman mereka.

Gropper dalam Aqib, (2013:69) menyatakan bahwa strategi pembelajaran merupakan pemilihan atas berbagai jenis latihan tertentu yang sesuai dengan tujuan pembelajaran yang ingin dicapai. Menurut Silberman, (2013:143) dalam bukunya yang berjudul Active Learning, 101 Strategis to Teach any Subject tentang uraian singkat strategi Everyone is a teacher Here menyatakan bahwa strategi ini mudah untuk memancing partisipasi seluruh murid dan tanggung jawab perorangan. Strategi ini memberi kesempatan kepada setiap murid untuk bertindak sebagai "Guru" bagi murid-murid lainnya. Strategi ini juga dapat meningkatkan keterampilan siswa mengkomunikasikan apa yang ada di dalam pikiran atau perasaan siswa kepada orang lain baik secara lisan maupun secara tertulis, sehingga memunculkan ide-ide baru yang dapat menambah pengetahuan siswa tentang dunia luar yang berhubungan dengan materi pembelajaran yang sedang dipelajari di kelas.

Prosedur dalam pembelajaran strategi everyone is a Teacher Here sebagai berikut: (1) Guru membagikan kartu indeks kepada setiap siswa kemudian meminta siswa untuk menuliskan pertanyaan yang mereka miliki tentang materi pembelajaran yang sedang dipelajari di kelas. (2) Mengumpulkan kartu, kemudian mengacak kartu tersebut. Dan membagikannya kepada setiap siswa dengan ketentuan tidak ada siswa yang menerima kartunya sendiri. Kemudian minta siswa untuk memikirkan jawaban dari kartu indeks yang sudah diterima. (3) Menunjuk beberapa siswa untuk membacakan kartu yang mereka dapatkan dan menjelaskan jawabannya kepada teman-teman mereka di depan kelas secara bergantian. (4) Setelah masing-masing siswa menjelaskan jawabannya, mintalah kepada siswa lain untuk memberi tambahan atas apa yang telah dikemukakan oleh siswa yang membaca kartunya tersebut. (5) Melanjutkan langkah-langkah ini kepada siswa lain secara bergantian, bila waktunya memungkinkan. (Silberman, 2013)

Sejalan dengan strategi pembelajaran aktif type Everyone is a Teacher Here yang dapat memberikan kesempatan dan waktu kepada siswa untuk membangun dan menemukan sendiri konsep pengetahuannya. Sebagai filsafat belajar, konstruktivisme sudah terungkap dalam tulisan ahli filsafat Giambattista Vico tahun 1970, yang mengemukakan bahwa orang hanya dapat memahami apa yang direkonstruksinya sendiri Suprijono, (2011:55).

Pandangan konstruktivisme mempunyai implikasi yang mendalam dalam pengajaran, sebab teori ini menganjurkan peranan yang lebih aktif pada siswa dalam pembelajaran mereka sendiri. Di dalam kelas yang demikian, maka peran guru adalah menemukan fakta, konsep, atau prinsip bagi diri mereka sendiri, bukan memberikan ceramah atau mengendalikan seluruh kegiatan kelas.

Penerapan strategi pembelajaran perlu mempertimbangkan desain pembelajaran yang dapat membantu tercapainya tujuan pembelajaran yang diinginkan. Eggen dan Kauchak menyatakan bahwa model pembelajaran memberikan kerangka dan arah bagi guru untuk mengajar (Trianto, 2011:5). Ada berbagai macam model pembelajaran yang bisa digunakan untuk mengajar di kelas. Model pembelajaran kooperatif merupakan sistem pengajaran yang memberi kesempatan kepada siswa untuk bekerja sama dengan sesama siswa dalam tugas-tugas yang terstruktur. Pembelajaran kooperatif dikenal dengan pembelajaran secara kelompok atau kerja kelompok karena dalam belajar kooperatif ada struktur 
dorongan atau tugas yang bersifat kooperatif sehingga memungkinkan terjadinya interaksi secara terbuka dan hubungan yang bersifat interdepedensi efektif diantara anggota kelompok (FaridliE., 2011:56)

Johnson serta Hilke (Faridli.E.,2011:52) mengemukakan ciri-ciri model pembelajaran kooperatif adalah terdapat saling ketergantungan yang positif diantara anggota kelompok, dapat dipertanggung jawabkan secara individu, berbagi kepemimpinan, tanggung jawab, menekankan pada tugas dan kebersamaan, membentuk keterampilan sosial, peran guru mengamati proses belajar siswa, efektivitas belajar tergantung pada kelompok, dan proses belajar terjadi dalam kelompok-kelompok kecil yang bersifat heterogen.

Menurut Ibrahim (dalam Trianto, 2011:48-49) langkah-langkah model pembelajaran kooperatif diantaranya yaitu sebagai berikut : (1) menyampaikan tujuan dan mempersiapkan siswa; (2) menyajikan informasi; (3) mengorganisir siswa ke dalam tim-tim belajar; (4) membantu kerja tim dan belajar; (5) evaluasi; dan (6) memberikan pengakuan atau penghargaan.

Berbagai penelitian yang dilakukan dalam bidang pembelajaran IPA saat ini lebih menekankan pada siswa daripada gurunya. Dengan upaya yang lebih menekankan bagaimana anak belajar, kita dapat melihat bahwa pembelajaran IPA di kelas dipandang sebagai suatu proses aktif, dan sangat dipengaruhi oleh apa yang sebenarnya ingin dipelajari siswa (Samatowa, 2011:9). Oleh karena itu salah satu bagian penting dalam memberdayakan siswa dalam pembelajaran IPA adalah kegiatan bertanya, bahkan menjadi bagian yang paling utama dalam pembelajaran. Melalui kegiatan bertanya, siswa akan berlatih menyampaikan gagasan dan memberikan respon. Bertanya merupakan ciri utama dalam pembelajaran IPA, dengan berbagai pertanyaan yang diajukan, IPA dapat dikembangkan untuk membangun pengetahuan baru selama pembelajaran (Samatowa, 2011:10).

Melalui penerapan strategi Everyone is a Teacher Here pada model pembelajaran kooperatif diharapkan dapat mendeskripsikan aktivitas guru dan siswa selama pembelajaran, juga meningkatkan keterampilan berpikir kritis siswa karena jika dilihat dari segi kognitif siswa, melalui variasi pertanyaan dan jawaban yang didiskusikan bersama, siswa akan menciptakan pemahaman terhadap materi yang dipelajari. Dengan pemahaman yang dibangun sendiri lewat bahasa siswa, memudahkan siswa untuk mengingatnya lebih dalam sehingga mampu mengerjakan soal evaluasi dan hasil belajar kognitif membaik. Dari segi afektif dan psikomotor siswa, melalui penerapan strategi pada model pembelajaran ini, siswa memiliki tanggung jawab individu (menjawab pertanyaan yang didapat) maupun tanggung jawab kelompok dalam mengerjakan tugas kelompok, sehingga diharapkan siswa mampu meningkatkan keterampilan afektif dan psikomotornya.

\section{Metode Penelitian}

Penelitian ini menggunakan metode Penelitian Tindakan Kelas (PTK) dengan model penelitian Kemmis dan Mc Taggart (Dwitagama, K,. dan Kusumah, 2012:21) pelaksanaan PTK meliputi 3 langkah, yaitu: 1) Planning-Perencanaan, 2) Acting \& Observing- Tindakan dan Pengamatan, 3) ReflectingPerefleksian. Ketiga komponen tersebut saling berkaitan sehingga disebut dengan siklus. Jumlah siklus pembelajaran ditentukan dari ketercapaian tujuan penelitian yang telah disusun. Apabila tujuan penelitian sudah dapat dicapai, tidak akan dilanjutkan pada siklus berikutnya, apabila ingin memaksimalkan penelitian maka dilanjutkan ke siklus berikutnya. Adapun prosedur penelitian yang dilaksanakan yaitu membuat perencanaan penelitian yaitu menyusun serangkaian kegiatan secara menyeluruh berupa siklus-siklus ataupun tahapan-tahapan penelitian tindakan kelas, menyusun instrumen penelitian sebagai pedoman terhadap pembelajaran selama penelitian tindakan kelas, penelitian ini dilakukan dengan kegiatan per siklus yaitu perencanaan, tindakan dan observasi serta refleksi.

Tahapan perencanaan meliputi analisis kurikulum, pembuatan perangkat pembelajaran, mempersiapkan media, menyiapkan instrumen serta menentukan indikator keberhasilan. Selanjutnya, tahapan pelaksanaan tindakan meliputi, segala tindakan yang mengaplikasikan segala perencanaan yang telah disiapkan. Kegiatan ini tertuang dalam rencana pelaksanaan pembelajaran (RPP) dengan menerapkan strategi Everyone is a Teacher Here pada model pembelajaran kooperatif. Serta tahapan pengamatan merupakan tahap pengumpulan data melalui melalui lembar observasi untuk mengamati aktivitas guru, dan aktivitas siswa. Dan terakhir adalah tahapan refleksi dilakukan melalui diskusi dengan guru kelas, serta teman sejawat mengenai hasil pengamatan yang dilakukan.

Adapun subyek penelitian ini adalah siswa-siswi kelas IV SD Hidayatul Mubtadiin dengan jumlah siswa 26 yang terdiri dari 14 siswa laki-laki dan 12 siswa perempuan. Lokasi penelitian dilaksanakan di kelas IV SD Hidayatul Mubtadiin Kota Pasuruan yang berada di Kelurahan Sebani, Kecamatan Gadingrejo, Kota Pasuruan. 
Teknik pengumpulan data yang digunakan pada penelitian ini adalah teknik observasi, tes, dan angket. Teknik observasi dilakukan untuk memperoleh data tentang aktivitas guru dan siswa saat pelaksanaan pembelajaran menerapkan strategi Everyone is a Teacher Here pada model pembelajaran kooperatif. Selain itu, teknik observasi juga digunakan peneliti untuk mengetahui hasil belajar siswa pada ranah afektif dan psikomotor. Selanjutnya, teknis tes digunakan untuk mengetahui peningkatan keterampilan berpikir kritis siswa dan hasil hasil belajar siswa pada ranah kognitif. Sedangkan angket digunakan untuk mengetahui bagaimana respon siswa terhadap pembelajaran IPA melalui penerapan strategi Everyone is a Teacher Here pada model pembelajaran kooperatif.

Dalam penilaian keterampilan berpikir kritis digunakan tes uraian berjumlah 10 soal yang disusun bedasarkan indikator Facione. Facione, (1990) mengemukakan bahwa keterampilan berpikir kritis meliputi: (1) interpretasi, (2) analisis, (3) evaluasi, (4) inferensi, (5) eksplanasi, dan (6) pengaturan diri.Data hasil belajar kognitif diperoleh dari 15 soal pilihan ganda dan 5 uraian yang dikembangkan berdasarkan indikator dan tujuan pembelajaran. Data hasil belajar psikomotor diperoleh dari penilaian unjuk kerja siswa dan kelompok dalam pembelajaran. Data aktivitas guru dan siswa diperoleh dari pengamat yang mengisi lembar observasi saat mengamati proses belajar mengajar pada setiap siklus. Sedangkan data respon siswa didasarkan data angket yang diberikan kepada siswa dengan memberitahukan bahwa angket tidak mempengaruhi nilai siswa.

Indikator keberhasilan dari penelitian ini adalah meningkatnya aktivitas guru dan siswa, meningkatnya keterampilan berpikir kritis siswa, meningkatnya kemampuan kognitif siswa, meningkatnya kemampuan afektif siswa, meningkatnya kemampuan psikomotor siswa, dan meningkatnya respon siswa. Apabila indikator keberhasilan penelitian sudah tercapai, maka penelitian dapat dihentikan dandibuat suatu simpulan dari hasil penelitian yang telah dilakukan

\section{Hasil dan Pembahasan}

Pada siklus I dan siklus II, hasil penelitian pelaksanaan pembelajaran IPA dengan menerapkan strategi Everyone is a Teacher Here pada model pembelajaran kooperatif dipaparkan sesuai dengan tahapan-tahapan dalam penelitian tindakan kelas, yaitu tahap perencanaan, pelaksanaan tindakan dan refleksi. Pada tahap perencanaan, peneliti melakukan persiapan untuk melaksanakan proses pembelajaran pada siklus I dan siklus II, yaitu sebagai berikut: (1) menganalisis kurikulum IPA kelas IV semester 1, (2) merancang perangkat pembelajaran yang terdiri dari silabus, Rencana Pelaksanaan Pembelajaran (RPP), Lembar Kerja Siswa (LKS), alat evaluasi, materi ajar (3)menyiapkan media pembelajaran, (4) menyusun instrumen yang akan digunakan dalam siklus PTK antara lain, lembar observasi aktivitas guru dan siswa, lembar tes keterampilan berpikir kritis dan kemampuan kognitif, lembar observasi penilaian afektif siswa, lembar observasi penilaian psikomotor, dan angket respon siswa, (5) validasi instrumen, dan (6) menyusun indikator keberhasilan. Adapun kriteria indikator keberhasilan yang dipergunakan oleh peneliti dalam siklus I dan siklus II yaitu nilai keterlaksanaan aktivitas guru dalam pembelajaran mencapai $\geq 80 \%$, skor ketercapaian aktivitas siswa mencapai $\geq 80 \%$, peningkatan keterampilan berpikir kritis dan kamampuan kognitif siswa mengalami peningkatan minimal sedang, hasil belajar siswa ranah afektif dan psikomotor dianggap tuntas jika secara secara klasikal memperoleh skor $\geq 80 \%$.

Sementara itu, tahap observasi pada siklus I dan siklus II terhadap aktivitas guru dan siswa dalam proses pembelajaran diamati oleh dua pengamat.Kegiatan pengamatan dilakukan bersamaan dengan proses pembelajaran. Dalam kegiatan observasi ini memperoleh hasil data aktivitas guru dan aktivitas siswa dalam menerapkan strategi Everyone is a teacher Here pada model pembelajaran kooperatif.

Berikut disajikan data hasil pengamatan aktivitas guru dan siswa selama dua siklus:

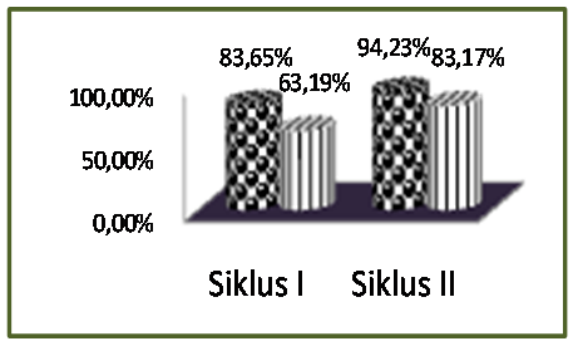

Diagram 1. Persentase Aktivitas Guru dan Siswa

Berdasarkan diagram diatas dapat diketahui bahwa terjadi peningkatan pada aktivitas guru. Siklus I persentase aktivitas guru telah mencapai 83,65\%, yang berarti telah memenuhi indikator keberhasilan 
yang diharapkan. Namun hal ini tetap ditingkatkan supaya pembelajaran pada siklus II lebih sempurna. Pada siklus II, guru memperbaiki kekurangan-kekurangan yang terjadi di siklus I yaitu antara lain memperjelas penyampaian tujuan pembelajaran, membimbing siswa dengan lebih efektif dan mengoptimalkan prosedur pemotivasian siswa agar siswa mau aktif dalam pembelajaran. Hasil dari perbaikan ini menunjukkan aktivitas guru pada siklus II meningkat menjadi 94,23\%.

Berdasarkan diagram diatas juga dapat diketahui bahwa terjadi peningkatan pada aktivitas siswa siklus I ke siklus II. Siswa lebih aktif dalam mengikuti kegiatan pembelajaran sehingga terjadi peningkatan persentase aktivitas siswa dari $63,19 \%$ pada siklus I menjadi $83,17 \%$ pada siklus II. Persentase pada siklus II sebesar $83,17 \%$ telah mencapai indikator keberhasilan penelitian, sehingga penelitian dianggap telah berhasil.

Untuk melihat besar peningkatan kemampuan kognitif siswa dapat dianalisis menggunakan rumus $\mathrm{N}$-Gain. Derajat peningkatan hasil belajar siswa ranah kognitif dapat dilihat pada Diagram 2.

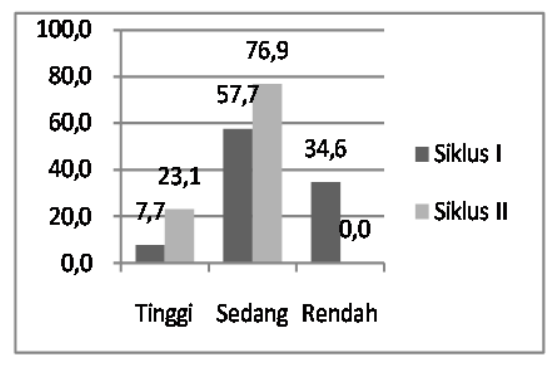

Diagram 2. Peningkatan Hasil Belajar Siswa Siklus 1 dan 2

Peningkatan hasil belajar ranah kognitif siswa pada siklus I, 7,7\% (2 siswa) menunjukkan peningkatan berkategori tinggi, 57,7\% (15 siswa) menunjukkan peningkatan sedang, dan 34,6\% (9 siswa) menunjukkan peningkatan rendah. Sedangkan pada siklus II, 23,1\% (6 siswa) menunjukkan peningkatan berkategori tinggi, 76,9 (20 siswa) menunjukkan peningkatan berkategori sedang, dan 0\% (0 siswa) menunjukkan peningkatan berkategori rendah.

Berdasarkan diagram diatas dapat diketahui bahwa terjadi peningkatan pada hasil belajar siswa ranah kognitif. Dalam siklus pertama masih terdapat 9 siswa dengan peningkatan rendah, sedangkan pada siklus kedua sudah tidak terdapat siswa dengan peningkatan rendah.

Untuk melihat besar peningkatan keterampilan berpikir kritis siswa dapat dianalisis menggunakan rumus N-Gain. Derajat peningkatan keterampilan berpikir kritis siswa dapat dilihat pada Diagram 3.

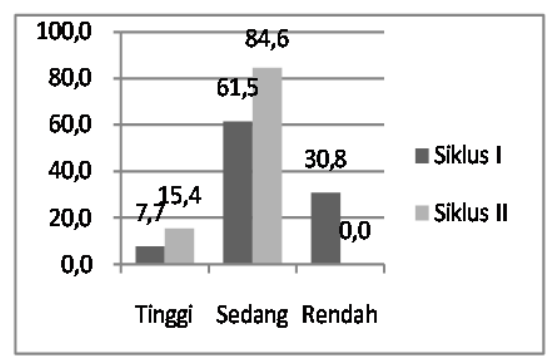

Diagram 3. Peningkatan Keterampilan Berpikir Kritis Siswa Siklus 1 dan 2

Peningkatan keterampilan berpikir kritis siswa pada siklus I, 7,7\% (2 siswa) menunjukkan peningkatan berkategori tinggi, 61,5\% (16 siswa) menunjukkan peningkatan sedang, dan 30,8\% (8 siswa) menunjukkan peningkatan rendah. Sedangkan pada siklus II, 15,4\% (4 siswa) menunjukkan peningkatan berkategori tinggi, 84,6\% (22 siswa) menunjukkan peningkatan berkategori sedang, dan 0\% (0 siswa) menunjukkan peningkatan berkategori rendah.

Berdasarkan diagram diatas dapat diketahui bahwa terjadi peningkatan pada keterampilan berpikir kritis siswa. Dalam siklus pertama masih terdapat 8 siswa dengan peningkatan rendah, sedangkan pada siklus kedua sudah tidak terdapat siswa dengan peningkatan rendah.

Untuk melihat perbandingan presentasi klasikal ranah afektif pada siklus I dan siklus II, maka disajikan diagram data hasil belajar siswa ranah afektif berikut. 


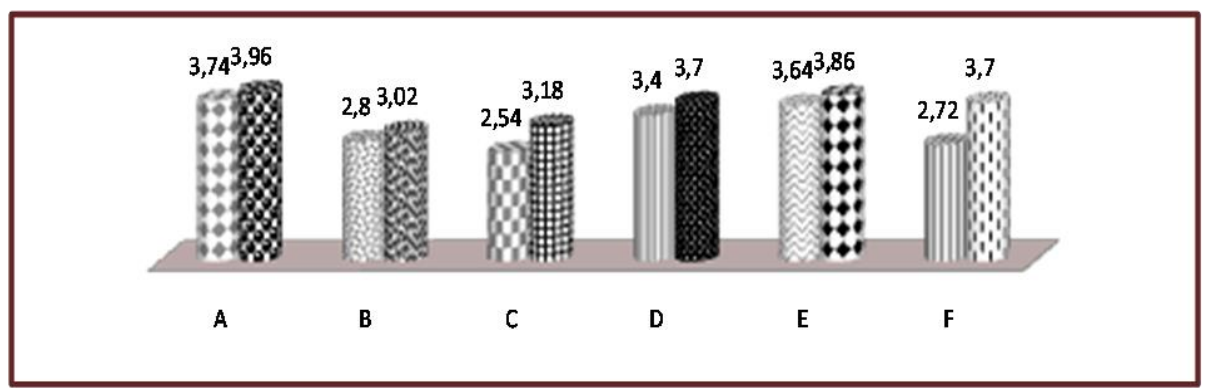

Diagram 4. Perbandingan Persentase Klasikal Tiap Sikap Afektif Siklus I dan Siklus II.

Keterangan : $\mathrm{A}=$ Kejujuran, $\mathrm{B}=$ Tanggung jawab, $\mathrm{C}=$ Keberanian, $\mathrm{D}=$ terbuka, $\mathrm{E}=$ Mendengarkan penjelasan Guru, F = Kerjasama, Penilaian : 4 = Baik sekali, 3 = baik, 2 = cukup, 1 = kurang.

Berdasarkan diagram diatas dapat diketahui bahwa terjadi peningkatan pada hasil belajar siswa ranah afektif pada tiap aspek sikapnya. Untuk peningkatan skor tiap aspeknya dapat dilihat pada diagram di atas. Dalam dua siklus terjadi peningkatan persentase ketuntasan hasil belajar siswa afektif dari siklus I ke siklus II. Pada siklus I masih terdapat hasil belajar ranah afektif dengan kategori cukup. Namun pada siklus II, hasil belajar ranah afektif sudah meningkat menjadi berkategori baik.

Selanjutnya disajikan data hasil belajar siswa ranah psikomotor selama dua siklus:

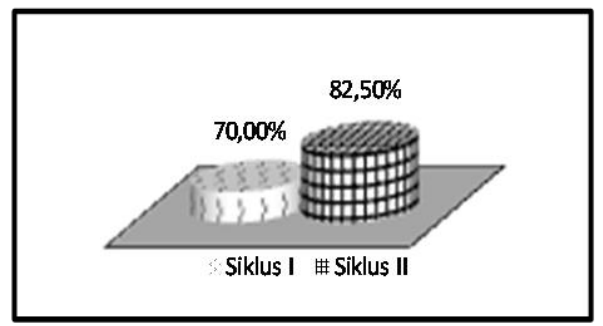

Diagram 5. Persentase Hasil Belajar Psikomotor Siswa

Berdasarkan tabel diatas dapat diketahui bahwa terjadi peningkatan pada hasil belajar siswa ranah psikomotor. Dalam dua siklus terjadi peningkatan persentase ketuntasan hasil belajar siswa psikomotor dari $70 \%$ pada siklus I menjadi $82,5 \%$ pada siklus II. Hasil belajar siswa mengalami peningkatan sebesar 12,5\%. Persentase pada siklus II sebesar $82,5 \%$ telah mencapai indikator keberhasilan sehingga penelitian dianggap telah berhasil.

Setelah dilakukan kegiatan penelitian baik siklus I dan siklus II, guru kelas bersama peneliti beserta teman sejawat mengadakan refleksi untuk mengetahui kelebihan dan kekurangan masing-masing tindakan yang telah dilakukan. Berdasarkan hasil pengamatan terhadap aktivitas guru, aktivitas siswa, dan hasil belajar siswa, Pembelajaran siklus II pada umumnya berjalan baik dengan beberapa kelebihan dan kekurangan yang terjadi dalam proses belajar mengajar.

Berdasarkan seluruh data yang diperoleh pada pelaksanaan siklus I dan II, dapat diketahui bahwa pembelajaran yang dilaksanakan pada siklus II telah mencapai seluruh persentase yang ditetapkan pada indikator keberhasilan, baik aktivitas guru dan aktivitas siswa,keterampilan berpikir kritis, kemampuan kognitif siswa, kemampuan afektif, kemampuan psikomotor. Dengan demikian kegiatan penelitian tidak dilanjutkan ke siklus selanjutnya.

Setelah penelitian dinyatakan berhenti setelah siklus II, maka peneliti memberikan angket untuk mengetahui respon siswa. Adapun hasil dari respon siswa adalah sebagai berikut.

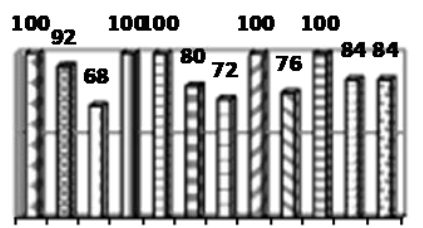

$\begin{array}{llllllllllll}1 & 2 & 3 & 4 & 5 & 6 & 7 & 8 & 9 & 1011 & 12\end{array}$

Diagram 6. Perhitungan Angket Respon Siswa 
Berdasarkan diagram di atas dapat diketahui bahwa, siswa merespon positif terhadap pembelajaran yang telah dilakukan. Hal ini terlihat pada pernyataan 1 yaitu $100 \%$ siswa menyatakan sangat setuju bahwa pembelajaran IPA pada materi penyesuaian diri makhluk hidup dengan lingkungannya menyenangkan dan tidak membosankan.Hal ini dikarenakan guru membuat suasana menyenangkan dengan berbagai cara seperti memperlihatkan media slide show yang berisi gambar menarik. Guru juga mencairkan suasana belajar dengan mewajibkan setiap kelompok membunyikan yelyel.

Pada pernyataan 2 sekitar 92\% siswa merespon positif yang menyatakan bahwa setelah melakukan pembelajaran ini, siswa percaya diri untuk mengajukan pertanyaan, menjawab, maupun menanggapi apa yang siswa kurang pahami pada materi yang diajarkan. Pada pernyataan 3 sekitar 68\% siswa merespon positif yang menyatakan bahwa siswa lebih senang menuliskan sebuah pertanyaan/topik yang tidak dipahami oleh siswa untuk kemudian dibahas di kelas pada kartu indeks. Hal ini juga berarti bahwa sekitar 32\% siswa lebih senang menuliskan sebuah pertanyaanyang telah mereka pahami untuk kemudian dijawab oleh teman lainnya, hal ini menunjukkan suatu sikap evaluasi antar siswa.

Respon siswa sangat baik terhadap model pembelajaran kooperatif yang menekankan kerjasama kelompok dalam menyelesaikan tugas, terutama pada saat mengerjakan LKS. Hal ini terlihat dari respon siswa pada pernyataan 4, yaitu $100 \%$ siswa merespon positif dengan menyatakan bahwa bekerja secara berkelompok melatih bekerjasama dengan orang lain. Didukung dengan perolehan respon siswa pada pernyataan 5. Sebesar $100 \%$ siswa merespon positif dengan menyatakan senang melakukan pembelajaran dengan diskusi. Hal ini dikarenakan guru mengadakan suasana pembelajaran diskusi yang berbeda dengan diskusi biasanya. Guru memberikan suasana kompetisi yang membuat seluruh siswa antusias menjadi kelompok terbaik. Di akhir pembelajaran, kelompok terbaik akan mendapatkan sebuah reward yang menarik. Sesuai dengan pernyataan yang dikemukakan Lie (Sanjaya, 2008:248) bahwa pengakuan tim sangat penting perannya untuk memotivasi tim agar lebih meningkatkan prestasi mereka.

Pada pernyataan selanjutnya, yaitu pernyataan 6, sebanyak 80\% siswa merespon positif menyatakan senang melakukan presentasi. Pada pernyataan 7 , sekitar $72 \%$ siswa menyatakan tidak kesulitan menjawab soal pada kartu indeks yang diterimanya, karena didiskusikan bersama saat maju ke depan kelas. Pembelajaran dengan menerapkan strategi Everyone is a Teacher Here pada model pembelajaran kooperatif membantu siswa dalam memahami materi yang sedang diajarkan di kelas. Hal ini ditunjukkan dari respon positif siswa sebesar $100 \%$ siswa setuju dengan pernyataan yang mengemukakan bahwa dengan menjawab pertanyaan pada kartu indeks yang telah diterima siswa telah membuatnya lebih paham tentang materi yang sedang diajarkan.Hal ini dikarenakan saat siswa mendapatkan pertanyaan yang agak sulit untuk dijawab, siswa yang lainnya membantu menjawab, sehingga terjadilah diskusi untuk memperoleh pemecahan masalah yang tepat dengan bahasa siswa sendiri. Hal tersebut membuat siswa lebih paham akan materi yang sedang diajarkan. Sesuai dengan filsafat belajar konstruktivisme yang mengemukakan bahwa orang hanya dapat memahami apa yang direkonstruksinya sendiri (Suprijono, 2011:55). Siswa juga senang melakukan diskusi kelas untuk menjawab satu-persatu masalah pada kartu indeks dengan persentase prespon positif siswa sebesar 76\%.

Pembelajaran yang dilakukan juga dapat membantu siswa dalam memahami materi/konsep pada materi penyesuaian makhluk hidup terhadap lingkungannya, terbukti dari $100 \%$ respon siswa pada pernyataan ke 10. Hal ini dikarenakan, pertanyaan-pertanyaan yang ditulis siswa tidak jauh dari materi yang sedang dipelajari. Sedangkan soal evaluasi disusun oleh guru berdasarkan materi yang diajarkan. Sehingga dengan menjawab pertanyaan dari teman, siswa melakukan pemantaban materi yang sedang dipelajari. Sesuai dengan pendapat Samatowa, (2011) yang menyatakan melalui kegiatan bertanya, siswa akan berlatih menyampaikan gagasan dan memberikan respons yang relevan terhadap suatu masalah yang dimunculkan sehingga membantu siswa memahami materi pelajaran. Dibuktikan dengan $84 \%$ siswa merespon positif dapat menyimpulkan materi pembelajaran yang telah diajarkan, serta $84 \%$ siswa menyatakan dapat menyelesaikan soal-soal yang berhubungan dengan materi dengan benar. Secara keseluruhan, rata-rata hasil respon siswa terhadap pembelajaran yang telah dilakukan adalah sebesar $88 \%$ yang tergolong kriteria baik.

Bukan hanya itu, 84\% siswa merespon positif dapat menyimpulkan materi pembelajaran yang telah diajarkan, serta 84\% siswa menyatakan dapat menyelesaikan soal-soal yang berhubungan dengan materi dengan benar. Secara keseluruhan, rata-rata hasil respon siswa terhadap pembelajaran yang telah dilakukan adalah sebesar 88\% yang tergolong kriteria baik. Hal ini sesuai dengan penelitian yang dilakukan oleh Pratomo, Rosyidi, \& Karyanto, (2012) bahwa pembelajaran dengan menerapkan strategi Everyone is a Teacher Heredapat meningkatkanminat belajar siswa dan memperoleh respon yang positif dari siswa.

Oleh karena itu, dapat disimpulkan bahwa pembelajaran IPA dengan menerapkan strategi Everyone is a Teacher Here pada model pembelajaran kooperatif dapat diterima siswa dengan baik. Sesuai dengan 
pendapat yang disajikan dalam kajian pustaka sebelumnya bahwa, pembelajaran dengan teman sebaya sangat baik. Karena setiap siswa saling menyampaikan pengetahuannya sesuai dengan pengalaman masing-masing. Jadi pengalaman siswa berkembang semakin mendalam dan semakin kuat ditambah dengan pengalaman baru yang dimiliki oleh siswa yang lain. Penggunaan bahasa siswa sendiri lebih mudah membentuk skema dan mengubah skema, dan individu sendiri yang merekonstruksi pengetahuan ketika berinteraksi dengan pengalaman obyek yang dihadapi (Magfiroh, 2012).

Hasil penelitian penerapan strategi Everyone is a Teacher Here pada model pembelajaran kooperatif untuk meningkatkan keterampilan berpikir kritis dan hasil belajar siswa kelas IV SD Hidayatul Mubtadiinmencapai hasil yang maksimal. Secara keseluruhan siswa mengikuti pembelajaran dengan baik selama pelaksanaan siklus I dan siklus II. Peningkatan hasil belajar kognitif siswa ini, erat hubungannya dengan aktivitas siswa dalam pembelajaran IPA dengan menerapkan strategi Everyone is a Teacher Here pada model pembelajaran kooperatif. Dalam penerapan strategi pada model ini, siswa telah diajarkan membentuk konsep belajarnya sendiri. Dengan membuat dan menjawab pertanyaan yang berkaitan dengan materi, siswa telah melakukan pemantaban materi yang sedang dipelajari. Hal ini sesuai dengan pernyataan yang dikemukan Samatowa, (2011:10) bahwa salah satu bagian penting dalam memberdayakan siswa dalam pembelajaran IPA adalah kegiatan bertanya. Hal ini sejalan dengan penelitian yang dilakukan oleh Hendra, Meter, \& Negara, (2013), Anggraeni, (2011) dan Rieska, (2012) bahwa penerapan strategi Everyone is a Teacher Heredapat meningkatkanprestasi belajar siswa.

Melalui kegiatan bertanya, siswa akan berlatih menyampaikan gagasan dan memberikan respon sehingga IPA dapat dikembangkan untuk membangun pengetahuan baru selama pembelajaran.Dalam pembelajaran ini siswa diharuskan menjawab pertanyaan di depan kelas, sehingga semua teman lainnya mendengarkan, maka jawaban didengar oleh semua siswa. Siswa yang sebelumnya belum tahu menjadi tahu, sedangkan siswa yang sebelumnya telah mengerti, menjadi semakin mengerti. Hal ini terbukti dengan hasil belajar kognitif siswa yang semakin meningkat. Lie (Isjoni, 2009) mengungkapkan bahwa pengajaran oleh teman sebaya lebih efektif daripada pengajaran oleh guru. Ini berarti, keberhasilan dalam belajar bukan semata-mata harus diperoleh dari guru saja, melainkan dapat juga dilakukan melalui teman lain, yaitu teman sebaya.

Hasil belajar ranah afektif juga mengalami peningkatan. Keberhasilan pencapaian indikator hasil belajar afektif siswa diperoleh dari penerapan strategi Everyone is a Teacher Here pada model pembelajaran kooperatif, yang didalamnya guru memberikan pengalaman sikap belajar pada siswa meliputi kejujuran, tanggung jawab, keberanian, terbuka, mendengarkan penjelasan guru dengan baik, dan kerjasama. Berdasarkan pengamatan, semua aspek sikap (afektif) yang diamati tersebut telah muncul ketika proses pembelajaran berlangsung. Ketika siswa melakukan diskusi kelompok, banyak aspek yang mengalami peningkatan yaitu kerjasama dan tanggung jawab. Melalui kerjasama yang baik, siswa dapat membangun rasa tanggung jawab bersama dengan baik pula. Dalam pembelajaran kelompok, guru melakukan pembimbingan kelompok secara efektif sehingga siswa saling membantu antar anggota, membagi tugas secara merata, dan hasilnya yang belum mampu menjadi mampu memahami materi yang tengah dipelajari karena didiskusikan bersama. Sesuai dengan pendapat Huda, (2013:113) yang menyatakan bahwa dalam pembelajaran kelompok, siswa maupun guru memiliki status yang sama namun peran yang berbeda dalam mengefektifkan pembelajaran. Siswa berperan sebagai pelaksana diskusi, sementara guru bertugas sebagai fasilitator dalam mendesain lingkungan kooperatif yang kondusif.

Selain itu, penerapan strategi Everyone is a Teacher Here pada model pembelajaran kooperatif juga dapat meningkatkan sikap keberanian, kejujuran, keterbukaan, dan tanggung jawab individu siswa. Dalam pembelajaran yang telah dilakukan dengan menerapkan strategi dan model pembelajaran ini, guru membagikan kartu indeks kepada setiap siswa dan menyuruh siswanya menuliskan pertanyaan di kartu tersebut. Mau tidak mau siswa dituntut untuk berperan aktif menjawab pertanyaan yang didapat dari temannya di depan kelas. Hal ini mengartikan bahwa setiap siswa selain memiliki tanggung jawab dalam kelompok, juga memiliki tanggung jawab individu, yaitu menjawab pertanyaan yang didapat. Sesuai dengan pendapat Silberman, (2013:171) yang menyatakan strategi pembelajaran ini mudah guna memperoleh partisipasi kelas yang besar dan tanggung jawab individu. Karena menjawabnya harus dilakukan di depan kelas, di hadapan semua teman-temannya, sedikit demi sedikit terpupuk keberanian dalam diri siswa. Terbukti pada aspek keberanian siswa meningkat dari Siklus I ke Siklus II. Sesuai pernyataan dari Depdiknas bahwa dalam pembelajaran kooperatif siswa yang lebih mampu akan akan menjadi narasumber bagi siswa lain yang kurang mampu, yang memiliki orientasi dan bahasa yang sama.

Aspek keterbukaan juga mengalami peningkatan dari Siklus I ke Siklus II. Melalui kegiatan diskusi kelompok maupun diskusi kelas, dapat meningkatkan keterbukaan dalam mengemukakan pendapat dan menerima pendapat dari teman lainnya untuk mendapatkan jawaban dari suatu permasalahan pada sebuah pertanyaan. Hal ini sesuai dengan pendapat Isjoni, (2009:46) yang menyatakan bahwa dengan 
berkelompok, siswa mendapat kesempatan yang lebih luas untuk mempraktekkan sikap dan perilaku berpartisipasi pada situasi sosial yang bermakna bagi mereka.

Berdasarkan pengamatan, keterampilan psikomotor yang diamati meliputi keterampilan menempelkan kartu fauna pada siklus I dan menempelkan kartu flora pada siklus II. Serta keterampilan membuat tabel pengamatan hasil diskusi kelompok. Melalui kegiatan diskusi kelompok, siswa diberi tugas menempelkan kartu fauna maupun kartu flora setelah mengamati tayangan video yang terkait dengan materi. Dari hasil pekerjaan siswa siklus I ke siklus II mengalami peningkatan pada aspek kerapian dan kekreatifitasan dalam penyajian hasil kelompok. Sehingga keterampilan siswa pada aspek menempelkan kartu fauna dan kartu flora mengalami peningkatan. Dalam pembelajaran yang bermakna perlu ditekankan pembelajaran yang berorientasi pada proses. Menurut (Slavin, 2014) pembelajaran bermakna terjadi apabila suatu informasi baru masuk ke dalam pikiran yang terkait dengan pengetahuan yang dipelajari sebelumnya. Agar terjadi pembelajaran yang dapat meningkatkan pemahaman siswa diperlukan sebuah konteks yang tepat bagi siswa yaitu dengan menerapkan pembelajaran yang mengacu pada keterampilan proses (Foulds \& Rowe, 1996).

Pemaparan peningkatan hasil belajar siswa diatas tidak terlepas dari pengaruh peningkatan aktivitas guru dan siswa dalam proses pembelajaran. Peningkatan ini terjadi dikarenakan guru memperbaiki kekurangan-kekurangan yang terjadi pada siklus I. Antara lain pada tahap penyampaian tujuan pembelajaran, meningkatkan keterampilan bimbingan siswa dalam mengerjakan LKS, tahap pembimbingan presentasi hasil kelompok, tahap pengumpulan dan pengacakan kartu indeks, tahap memerankan siswa menjadi guru bagi siswa lainnya, dan tidak kalah pentingnya yaitu meningkatkan aktivitas guru dalam prosedur pemotivasian siswa. Peningkatan aktivitas guru dalam menjalankan pembelajaran dengan strategi Everyone is a Teacher Here pada model pembelajaran kooperatif, sangat mempengaruhi terhadap aktivitas siswanya. Seperti yang tersaji pada diagram sebelumnya. Terbukti dari siklus I ke siklus II, aktivitas siswa menunjukkan peningkatan. Aktivitas guru telah meningkat pada tiap tahapnya. Hal ini sangat mempengaruhi peningkatan aktivitas siswa. Sesuai dengan teori konstruktivis yang mengemukakan bahwa satu prinsip penting dalam psikologi pendidikan adalah guru tidak hanya sekedar memberikan pengetahuan kepada siswa, melainkan siswa sendiri yang harus membangun dalam benaknya (Nur dalam Trianto, 2011:14).

Selain itu, aktivitas guru dalam menyampaikan tujuan pembelajaran dan menyajikan informasi juga mempengaruhi aktivitas siswa dalam mengerjakan soal evaluasi. Karena guru menyampaikan tujuan pembelajarannya secara gamblang dan jelas, serta menyampaikan informasi dengan cara yang menarik, sehingga menarik perhatian siswa untuk mendengar dan memperhatikannya sehingga meningkatkan pemahaman siswa terhadap materi dan berujung pada hasil belajar kognitif yang meningkat. Hal ini sesuai dengan pernyataan bahwa setiap guru harus memahami akan alasan mengapa suatu mata pelajaran perlu diajarkan. Demikian pula halnya dengan guru IPA harus tahu benar kegunaan-kegunaan apa saja yang dapat diperoleh dari pelajaran IPA (Samatowa, 2011:6).

Guru juga meningkatkan pemotivasian terhadap siswa dengan melakukan beberapa kegiatan yang bisa membuat siswa bekerja dengan kekompakan. Hal ini dilakukan guru dengan cara menyuruh setiap kelompok untuk menciptakan dan membunyikan sorak yel-yel kelompok masing-masing setiap akan maju presentasi hasil kerja. Tidak hanya itu, guru juga meningkatkan aktivitasnya dalam membimbing siswa mengerjakan LKS dengan cara menyajikan bahan pengamatan yang lebih konkret yang bisa diamati siswa secara langsung pada objeknya. Dengan begitu, hasrat eksplorasi siswa lebih meningkat, dan membuatnya fokus dalam kerja kelompok. Karena guru telah terampil membimbing kerja kelompok siswa, siswa telah belajar mandiri dengan semangat untuk menyelesaikan tugasnya secara berkelompok. Mencari tahu jawaban dari permasalahan dengan mendiskusikan bersama anggota kelompoknya. Hal ini meningkatkan hasil belajar afektif siswa dalam aspek sikap kerjasama, keterbukaan, dan tanggung jawab siswa.

Aktivitas guru pada tahap memerankan siswa sebagai guru telah menunjukkan peningkatan. Guru menambah usahanya dalam memotivasi siswa untuk aktif berpartisipasi dalam diskusi kelas. Guru telah melakukannya dengan berbagai cara, diantaranya dengan cara mengenal lebih jauh tentang pribadi siswa, dan menjelaskan keuntungan positif yang akan didapat dengan aktif berdiskusi. Hal ini terbukti efektif untuk meningkatkan aktivitas siswa saat siswa menjadi guru bagi siswa lainnya yaitu berani maju ke depan kelas tanpa disuruh. Sesuai pendapat Lie (Sanjaya, 2008:248) yang menyatakan bahwa pengakuan dan pemberian penghargaan diharapkan dapat memotivasi tim lain untuk lebih mampu meningkatkan prestasi mereka.

Rata-rata siswa mampu menjawab pertanyaan dengan tegas dan lantang, memberikan tanggapan kepada temannya yang maju di depan kelas, juga mempertahankan pendapatnya dengan alasan yang logis. Dalam berbagai aspek aktivitas siswa tersebut telah terkandung unsur keberanian, tanggung jawab, serta keterbukaan dalam mengemukakan pendapat. Sehingga dengan meningkatnya aktivitas siswa tersebut telah meningkatkan berbagai aspek afektif siswa. Yaitu keberanian, tanggung jawab, dan 
keterbukaan dalam mengemukakan maupun menerima pendapat. Selain itu, melalui kegiatan pembacaan kartu indeks di depan kelas, dapat meningkatkan pemahaman siswa terhadap materi yang sedang dipelajari karena telah dimantabkan bersama-sama melalui diskusi kelas membahas jawaban dari soal pada kartu indeks, sehingga meningkatkan hasil belajar kognitif siswa.Sejalan dengan teori perkembangan Piaget mewakili konstruktivisme, yang memandang perkembangan kognitif sebagai suatu proses dimana siswa secara aktif membangun sistem makna dan pemahaman realitas melalui pengalaman-pengalaman dan interaksi-interaksi mereka sendiri (Trianto, 2011:14).

Aktivitas guru dalam tahap menyimpulkan materi pembelajaran juga meningkat karena guru telah melakukannya dengan melibatkan peran siswa dalam membuat kesimpulan. Dalam hal ini guru hanya membantu dan memberikan kesempatan besar pada siswa untuk menyimpulkan dan menuliskan rangkuman di papan tulis sehingga siswa lainnya bisa melihat dan memperkuat pemahaman terhadap materi sehingga hasil belajar kognitifnya meningkat.

Secara garis besar, kekurangan-kekurangan yang terjadi diakibatkan karena kurangnya motivasi guru terhadap siswa. Aktivitas guru dalam prosedur pemotivasian ini merupakan aktivitas tersirat yang sangat mempengaruhi aktivitas siswa. Oleh karena itu guru melakukan banyak cara untuk membuat siswanya aktif dalam pembelajaran. Selain cara-cara yang telah disebutkan di atas, guru juga melakukan pengenalan lebih jauh dengan siswa pada waktu senggang di luar jam pelajaran yaitu pada jam istirahat. Hal ini dilatar belakangi oleh peneliti yang merupakan guru pemula yang belum mengenal jauh pribadi siswa. Dari kegiatan penegenalan, dapat menambah informasi bagi guru mengenai faktor-faktor kebiasaan pasif atau malu berpendapat. Setelah itu guru memberikan motivasi kepada siswa berupa nasehat, arahan, pujian, untuk membuat siswa aktif dalam pembelajaran. Guru juga selalu mengingatkan tentang pentingnya kejujuran pada siswa, sehingga dari siklus I ke siklus II jumlah siswa yang tercatat mencontek ketika mengerjakan soal evaluasi berkurang. Aktivitas siswa dalam mengerjakan soal evaluasi pun meningkat.

Berdasarkan pembahasan diatas, dapat disimpulkan bahwa ketuntasan aktivitas guru dan aktivitas siswa mempengaruhi hasil belajar siswa baik ranah kognitif, afektif, maupun psikomotor. Ketuntasan aktivitas guru dalam pembelajaran merupakan faktor instrumental, sedangkan ketuntasan aktivitas siswa dalam pembelajaran merupakan faktor psikologis. Kedua faktor tersebut merupakan faktor yang mempengaruhi hasil belajar siswa. Seperti yang telah dikemukakan pada bagian kajian pustaka bahwa kedua faktor ini saling mendukung dan berinteraksi dalam membentuk hasil belajar siswa. Oleh karena itu, ketercapaian indikator keberhasilan aktivitas guru dan siswa mempengaruhi pula ketercapaian hasil belajar siswa.

Secara keseluruhan hasil yang didapatkan, telah sesuai dengan tujuan pembelajaran kooperatif yaitu untuk meningkatkan hasil belajar akademik, meningkatkan kinerja siswa dalam tugas-tugas serta membantu siswa dalam memahami konsep-konsep yang sulit. Bukan hanya itu, model ini dapat mengembangkan keterampilan sosial siswa yaitu keterampilan bekerjasama (Isjoni, 2009, p. 27).

Penelitian ini di dukung oleh penelitian Yanti, Haris, \& Tripalupi, (2017), bahwa Everyone is a Teacher Here dapat meningkatkan aktivitas dan hasil belajar dalam pembelajaran iPS kelas VIIIC SMP Negeri 2 sekasada. Penelitian tersebut sejalan dengan penelitian yang dilakukan oleh Sari, (2014) yang menunjukkan bahwa Everyone is a Teacher Here selain dapat meningkatkan kemandirian belajar siswa, juga dapat meningkatkan keterampilan berpikir kritis siswa. Selain itu penelitian oleh Liasari, Sudjarwo, \& Purnomo, (2017) menunjukkan hasil temuan penelitian, bahwa implementasi Everyone is A Teacher Here berpengaruh terhadap hasil belajar dan keterampilan berpikir kritis siswa. Adapun kendala yang dihadapi dalam pembelajaran adalah keterbatasan waktu belajar. Hasil penelitian ini menunjukkan bahwadengan menerapkan strategi everyone is a teacher here pada model pembelajaran kooperatif maka dapat meningkatan keterampilan berpikir kritis dan hasil belajar siswa SD. Hal ini mengandung implikasi agar kedepannya, guru-gurudapat menerapakan strategi everyone is a teacher here pada model pembelajaran kooperatifagar dapatmeningkatkan keterampilan berpikir kritis dan hasil belajar siswa SD.

\section{Simpulan dan Saran}

Berdasarkan hasil penelitian dan pembahasan yang telah dipaparkan sebelumnya, dapat disimpulkan bahwa penerapan strategi Everyone is a Teacher Here pada model pembelajaran kooperatif meningkatkan aktivitas guru, aktivitas siswa, dan hasil belajar IPA siswa, baik ranah kognitif, afektif, maupun psikomotor. Selain itu pembelajaran direspon positif oleh siswa. Hal tersebut dapat dibuktikan dengan data peningkatan aktivitas guru, siswa, hasil belajar,dan angket selama 2 siklus.

Berdasarkan hasil dan pembahasan yang diuraikan di atas, agar penerapan strategi Everyone is a Teacher Here pada model pembelajaran kooperatif berjalan efektif dalam meningkatkan hasil belajar IPA siswa, peneliti memberikan saran agar bisa meningkatkan aktivitas guru selama pembelajaran, guru 
diharapkan dapat menerapkan strategi dan model pembelajaran ini sesuai dengan langkah-langkahnya. Memperkaya wawasan tentang berbagai macam strategi dan model pembelajaran juga penting. Hal ini dapat dilakukan dengan cara banyak membaca sumber tentang berbagai macam strategi dan model pembelajaran dalam bentuk media cetak maupun elektronik.

Untuk meningkatkan aktivitas siswa, siswa dituntut terlibat aktif dalam pembelajaran, oleh karena itu guru harus bisa memotivasi siswa untuk membangkitkan semangat mereka. Hal ini dapat dilakukan dengan cara mengajak seluruh siswa berpartisipasi dalam setiap sub kegiatan pembelajaran, memberikan banyak kata motivasi, pujian, dan menghargai setiap usaha yang dilakukan setiap siswa.

Untuk meningkatkan hasil belajar IPA siswa, guru dituntut untuk lebih kreatif dalam memilih strategi dan model pembelajaran. Caranya yaitu dengan menerapkan strategi Everyone is a Teacher Here pada model pembelajaran kooperatif. Karena di dalamnya telah mengajarkan berbagai pengalaman belajar, sikap, dan keterampilan yang diperlukan untuk membuat siswanya terlibat aktif dalam memperoleh pemahaman yang lebih mendalam.

Untuk penelitian selanjutnya, hendaknya melakukan pembenahan pada langkah pembelajaran khususnya yang berkaitan dengan prosedur pemotivasian keaktifan siswa, karena hal ini sangat berpengaruh terhadap keberhasilan tindakan yang dilakukan. Juga perlu dipertimbangkan kesesuaian karakteristik kompetensi dasar yang ingin dicapai. Sebab tidak semua kompetensi dasar dapat dicapai dengan efektif jika diterapkan strategi dan model pembelajaran ini.

\section{Daftar Rujukan}

Ainurrahman. (2011). Belajar dan Pembelajaran. Bandung: Alfabeta.

Anggraeni, E. D. (2011). Peningkatan Pemahaman Konsep dan Hasil Belajar Operasi Dasar Bilangan Bulat Melalui Strategi Pembelajaran Everyone is a Teacher Here Alat Peraga Mistar Hitung Bagi Siswa Kelas VII Semester I SMP Bhakti Praja Mayong Jepara Tahun Ajaran 2010/2011. Universitas Muhammadiyah Surakarta.

Aqib, Z. (2013). Model-model, Media, dan Srategi Pembelajaran Kontekstual(inovatif). Bandung: Yrama Widya.

Dean, D., \& Kuhn, D. (2003). Metacognition and critical thinking. Educational Resources Information Center, $26,1-11$.

Dwitagama, K,. Kusumah, W. (2012). Mengenal Penelitian Tindakan Kelas. (PT. Indeks, Ed.). Jakarta.

Facione, P. A. (1990). Critical Thinking: A Statement of Expert Consensus for Purposes of Educational Assessment and Instruction Executive Summary “ The Delphi Report. The California Academic Press, 423(c), 1-19. https://doi.org/10.1016/j.tsc.2009.07.002

Faridli.E., H. S. (2011). Model-Model Pembelajaran Inovatif. Bandung: Alfabeta.

Foulds, W., \& Rowe, J. (1996). The enhancement of science process skills in primary teacher education students. Australian Journal of Teacher Education, 21(1), 2.

Hendra, I. K., Meter, I. G., \& Negara, I. G. A. O. (2013). Pengaruh Strategi Pembelajaran Aktif Tipe Everyone is aTeacher Hereterhadap Hasil Belajar IPAKelas IVSDN 2 Dangin Puri. MIMBAR PGSD Undiksha, 1(1).

Huda, M. (2013). Model-model Pengajaran Dan Pembelajaran. Yogyakarta: Pustaka Pelajar.

Isjoni. (2009). Cooperative Learning. Bandung: Alfabeta.

Jasdilla. 2017. Hasil Belajar dan Pembelajaran Kooperatif Tipe TPS. Jurnal Pendidikan Indonesia Vol. 6, No.1, April 2017

Lau, J. Y. F. (2011). An Introduction to Critical Thinking and Creativity: Think More, Think Better. An Introduction to Critical Thinking and Creativity: Think More, Think Better. https://doi.org/10.1002/9781118033449 
Liasari, V., Sudjarwo, S., \& Purnomo, E. (2017). Perbandingan Hasil Belajar Menggunakan Model Everyone Is A Teacher Here dan Make A Match. Jurnal Studi Sosial, 5(2).

Magfiroh, I. (2012). Penerapan Model Pembelajaran Dengan Strategi Setiap Siswa Berperan Sebagai Guru (Everyone is a Teacher Here)Pada Materi Perpindahan Kalor Di Kelas X SMA Negeri 1. Mojokerto. PGSD Universitas Negeri Surabaya (Tidak Diterbitkan).

Nardone, Wallace, Bassham, Irwin. (2011). Critical Thingking A Student's Introduction. New York: McGrawHill.

Pratomo, E. N., Rosyidi, A., \& Karyanto, P. (2012). Hasil Belajar Biologi Ranah Kognitif Ditinjau Dari Model Every One is a Teacher Here Dan Minat Belajar Siswa Kelas XI Di SMA Negeri 1 Sukoharjo. Jurnal Pendidikan Biologi, 4(3), 67-72.

Rieska, F. (2012). Implementasi Metode Pembelajaran Everyone Is A Teacher Here (Semua Bisa Jadi Guru) Dalam Meningkatkan Prestasi Belajar Sejarah Siswa Kelas XI IPS 2 SMAN 10 Yogyakarta Tahun Ajaran 2011/2012. Universitas Negeri Yogyakarta.

Samatowa, U. (2011). Pembelajaran IPA di Sekolah Dasar. Jakarta: PT. Indeks.

Sanjaya, W. (2008). Strategi Pembelajaran Berorientasi Standar Proses Pendidikan. Bandung: Kencana.

Sari, D. I. (2014). Penerapan Strategi Pembelajaran Everyone Is A Teacher Here Untuk Meningkatkan Kemandirian Belajar Ekonomi Siswa Kelas VIII C SMP Negeri 2 Colomadu Tahun Ajaran 2013/2014. Universitas Muhammadiyah Surakarta.

Silberman, M. (2013). Pembelajaran Aktif 101 Strategi Untuk Mengajar Secara Aktif. Jakarta: PT. Indeks.

Slavin, R. E. (Johns H. U. (2014). Educational Psychology Theory and Practice, Eighth Edition. Igarss 2014. https://doi.org/10.1007/s13398-014-0173-7.2

Suprijono, A. (2011). Cooperative Learning. Yogyakarta: Pustaka Pelajar.

Trianto. (2011). Model-Model Pembelajaran Inovatif Berorientasi Konstruktivistik. Jakarta: Prestasi Pustaka.

Trilling, B., \& Fadel, C. (2009). 21st Century Skills: Learning for Life in Our Times. 21st Century Skills Learning for life in our times.

Wagner, T. (2008). The Global Achievement Gap: Why Even Our Best Schools Don't Teach the New Survival Skills Our Children Need--And What We Can Do About It. American Education.

Yanfa'ani, P. S., Maridi, \& Dwiastuti, S. (2015). The influence of active knowledge sharing based contexstual learning models toward biology critical thingking. Jurnal Pendidikan Biologi, 7(1), 28-39.

Yanti, P. D. K., Haris, I. A., \& Tripalupi, L. E. (2017). Penerapan Metode Everyone is a Teacher Here (ETH) untuk Meningkatkan Aktivitas dan Hasil Belajar dalam Pembelajaran IPS Kelas VIII C SMP Negeri 2 Sekasada Tahun Pelajaran 2016/2017. Jurnal Pendidikan Ekonomi Undiksha, 9(1).

Yusuf, M. (2018). Pengembangan Perangkat Pembelajaran Berbasis Problem Based Learning untuk Meningkatkan Keterampilan Berpikir Kritis Peserta Didik Sekolah Dasar. Paedagoria/ FKIP UMMat, 9(1), 37-44. 